\title{
Government Subsidy Optimization in the Property Sector (Housing) in the Middle of the COVID-19 Pandemic
}

\author{
Aldarine Molidya ${ }^{1, *}$ Rolland E. Fanggidae ${ }^{2}$ \\ ${ }^{1,2, F a k u l t a s}$ Ekonomi, Nusa Cendana University, Kupang, Indonesia \\ *Corresponding author. Email: aldarinemolidya@gmail.com
}

\begin{abstract}
The research entitled Optimizing Government Subsidies in the Housing Sector in the Middle of the Covid19 Pandemic in Kupang City aims to explain the optimization of subsidies provided by the Government to the housing sector in the midst of the Covid19 pandemic in the city of Kupang. The results showed that there was a decline in the real estate sector (housing) amid the ongoing COVID-19 pandemic. This means that the decline occurred in the first and second quarters of 2020 in the real estate (housing) sector, but public interest in subsidized housing remained. This happens because the covid 19 conditions force people to stay indoors resulting in a decrease in people's income and purchasing power. So that it will force people to think about owning a private residence. In the first quarter, the real estate sector grew by $2.37 \%$ and in the second quarter there was a decrease to $2.25 \%$.
\end{abstract}

Keywords: COVID-19, Real estate Sector, Subsidized Housing

\section{INTRODUCTION}

The corona pandemic (Covid-19) that has hit the world in recent times has had quite an impact on all human activities, including the economy in Indonesia. All industrial and business sectors were affected, one of which was the property sector. Almost all property sectors from homes, apartments, offices, shops, hotels, industry, to warehousing have shown an increasing trend in sales in 2019, experiencing a decline during this pandemic. The results of a Bank Indonesia survey stated that the Residential Property Price Index (IHPR) in the first quarter of 2020 slowed 1.68 percent, lower than the previous quarter of 1.77 percent and the same period the previous year, which was 2.06 percent.

The real estate sector, especially housing, is one of the basic primary needs (primary) needed by humans in addition to clothing and food needs. Shelter need is a human's need to make a place to live. At first the function of the house was only for survival, but it has turned into a family residence. Fulfillment of housing needs is increasingly difficult to fulfill, along with increasing population growth resulting in higher land prices. One of the efforts made by the government to encourage the fulfillment of housing needs, it is necessary to provide housing provided by both the government and the private sector. Housing is classified according to the type of house by taking into account the level of affordability of the purchasing power of the Indonesian people [1] .

The Corona pandemic has indeed hit hard on the property sector in Indonesia. Based on data from the Indonesia Property Market Index Q1 2020, it also notes that overall, the property market trend in 2020 is to become a buyer's market. In other words, the momentum is right for consumers to own property.

For this reason, the government needs to pay serious attention to the property sector, this is because the property sector provides a multiplier effect because it is able to touch 174 other sectors while absorbing more than 30 million workers. So, the government hopes that people will not give up their intention when they want to buy a house.

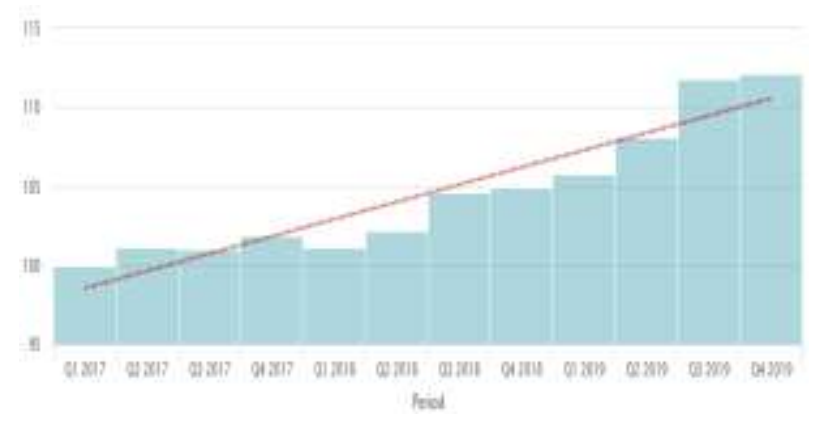

Figure 1 Indonesian Property Trend Source: Rumah.Com, compiled. 
The existence of a stimulus provided by the government through policies that are beneficial to developers, including the Interest Difference Subsidy (SSB) and Down Payment Subsidy (SBUM) for KPR for low-income people is expected to be able to convince developers to continue running their projects.

The need for housing in Indonesia continues to grow every year. Based on data from Real Estate Indonesia (REI), the total need for houses per year could reach 2.6 million driven by population growth, repair of damaged houses and a backlog or shortage of houses. The large number of housing needs in Indonesia, as is the case in the world community, especially in urban communities, with a large population, requires government efforts to deal with housing problems amidst various constraints such as limited housing land the need for housing results in higher house prices.

Housing financing assistance for FY 2020 through the Ministry of Public Works and Public Housing (PUPR) consists of three programs, namely the Housing Financing Liquidity Facility (FLPP), Savings-Based Housing Financing Assistance (BP2BT) and Additional Fiscal Stimulus through Interest Difference Subsidy (SSB).

The government's allocation for FLPP is 102,500 units valued at Rp. 11 trillion, BP2BT 9,500 worth Rp. 380 billion and SSB 175,000 units worth Rp. 788 billion. SSB consists of 155,000 regular SSB KPR units and 20,000 SSB KPR units for ASN, TNI and Polri. Currently, the progress of FLPP activities has reached 77,050 units worth Rp. 7.8 trillion, BP2BT with 147 units worth Rp. 5.84 billion and SSB 4,067 units worth Rp. 1.53 billion. The subsidized housing program has been launched since 2015 to make it easy for low-income people to have decent and affordable housing, thereby improving the welfare of the community.

The government has carried out the task of allocating funds and or development costs to support the realization of housing for Low-Income Communities (MBR) and facilitating the provision of housing and settlements for communities, especially for Low-Income Communities (MBR). Based on the Regulation of the Minister of Public Works and Public Housing Number 20 / PRT / M / 2014. Based on this description, implementation is a dynamic process, in which the policy implementer carries out an activity or activity, so that in the end it will get a result that is in accordance with the objectives or objectives of the policy itself.

In the implementation of the subsidized housing program, which is a dynamic process in which to get a result that is in accordance with the objectives which is influenced by the six variables proposed by Donald Van Meter and Van Horn. So based on the above background, the authors can formulate the problems discussed in this study are Optimization of Government Subsidies in the
Real Estate (Housing) Sector Amid the Covid19 Pandemic, Studies on the Real Estate sector in KupangNTT.

\section{THEORETICAL REVIEW}

\subsection{Housing}

Reference [2] concerning Housing and Settlements states that housing is a group of houses that function as a residential environment or a residential environment equipped with environmental infrastructure and facilities, while settlements are part of the environment outside a protected area, both in the form of urban and rural areas. serves as a residential or residential environment and a place for activities that support life and livelihood.

Housing and settlements are basic human needs. In Indonesian society, housing and its supporting infrastructure are a reflection of human identity, both individually and in unity and togetherness and harmony with the surrounding environment. Housing and settlements also have a very strategic role in shaping the character and personality of the nation, so they need to be nurtured and developed for the continuity and improvement of life and community livelihoods.

Housing and settlements, apart from functioning as a forum for human resource development and the embodiment of an orderly social environment, are also a contribution to economic growth through the housing industry sector as a provider of employment and a major driver of capital formation. By increasing and fulfilling the need for housing and settlements, it is hoped that the community can increase productivity, participate actively in development, and be able to increase capital accumulation for further development.

\subsection{Subsidized House Concept}

The government in carrying out coaching has the duty to allocate funds and or development costs to support the realization of housing for Low-Income Communities (MBR) and facilitate the provision of housing and settlements for communities, especially for Low-Income Communities (MBR). Based on the Regulation of the Minister of Public Works and Public Housing Number 20/PRT/M/2014 concerning Liquidity Facilities for Housing Financing in the Context of Acquiring a Prosperous Home for Low-Income Communities in Article 2 paragraph (1) that FLPP aims to support credit / financing of simple healthy home ownership ( KPR $\mathrm{RSH}$ ) for Low Income Communities (MBR).

Subsidies according to [3], are payments made by the government to companies or households to achieve certain goals that enable them to produce or consume a product in a larger quantity or at a lower price. With a lower price, the goods produced will be higher due to 
high public consumption. Economically, the purpose of subsidies is to reduce prices or increase output (output). Providing subsidies for consumers or the community basically aims to improve the welfare of the people which will have an impact on economic growth in a country.

In this research, subsidies/housing financing assistance is included in the form of subsidized goods provided to low-income groups in terms of meeting housing needs, namely in the form of houses with prices below market prices. The government provides housing financing assistance in the form of the Housing Financing Liquidity Facility (FLPP) program and these funds are combined with the funds of the executing bank in a certain proportion

\section{METHODS}

\subsection{Research Approach}

In this study, the approach used is quantitative descriptive analysis, namely research that seeks to explain a social phenomenon through data analysis in the form of numbers. The purpose of this research is to describe the nature of something that is taking place at the time of the study. Researchers used this research design because researchers wanted to know and provide an overview of what it is about Optimizing Government Subsidies in the Real Estate (Housing) Sector in the Middle of the Covid-19 Pandemic. This study focuses more on the data obtained, namely data on the growth of the real estate sector and data on subsidized funds (FLPP) and then analyzed and interpreted.

\subsection{Types and Sources of Data}

\subsubsection{Type of Data}

The used data in this research is quantitative data that has been processed. The quantitative data in question is data on the realization of subsidized houses based on salary groups, data on realization of subsidized FLPP funds based on type of work, data on the development of the number of houses financed through FLPP, data on growth in the real estate sector in East Nusa Tenggara in 2019-2020 and so on.

\subsubsection{Data Source}

In this research, researchers used secondary data. Secondary data is data obtained through intermediary media or indirectly in the form of financial reports, books, records, existing evidence, or archives, whether published or not. Data sources come from the official website of Bank Indonesia [4] and the official website of the Central Bureau of Statistics of East Nusa Tenggara [5].

\subsubsection{Data collection technique}

The data collection for this study is literature study. The literature study technique is carried out by collecting data based on sources obtained from the literature that discusses the growth and development of the real estate sector in Kupang, East Nusa Tenggara Province.

\section{RESULTS AND DISCUSSION}

Through [2] concerning Housing and Settlements, it gives high hopes for low-income people (MBR) to get a house. In accordance with the mandate of [2] on Housing and Settlements, the government issued a policy of providing housing subsidies. Housing subsidy is a credit that is allocated to people with middle to lower income in order to meet the needs of housing or repair of houses they already have. The subsidies provided are in the form of: subsidies for the difference in interest, additional development funds, and housing improvements.

Efforts to encourage home ownership are carried out by the government through the policy of providing housing subsidies. This is manifested in the Regulation of the State Minister for Public Housing of the Republic of Indonesia for [6] concerning the Procurement of Housing and Settlements with the Support of Subsidized Housing Facilities through Subsidized KPR / KPRS. Regulation of the Minister of Public Housing of the [7] concerning Amendments to the [6] concerning Procurement of Housing and Settlements with the Support of Subsidized Housing Facilities through Subsidized KPR / KPRS. In 2005, through the [6] , it was regulated on the policy of providing housing subsidies for people with low income and no housing.

People with a basic salary of less than IDR 1,000,000 in 2019 bought 243 subsidized houses, while in 2020 it decreased by buying 251 units of subsidized housing. For people with a basic salary of Rp. 1,000,000 - Rp. 1,500,000 in 2019 to buy subsidized houses of 1,332 units. And in 2020 it has decreased to 1,255 units. Meanwhile, people with a basic salary of Rp. 1,500,000 Rp. 2,500,000 in 2019 by 16,689 subsidized houses. And in 2020 there was a decrease to 16,096 subsidized housing units purchased. For people with a basic salary of Rp. 2,500,000 - Rp. 3,500,000 in 2019 to buy 35,521 subsidized houses. And in 2020, there was an increase in the number of 40,904 subsidized houses purchased. People with a basic salary of Rp. 3,500,000 - Rp. $4,000,000$ buy 23,811 subsidized housing units. And in 2020 , there is a significant increase by purchasing 32,697 subsidized houses. And people with a basic salary of more than Rp. 4,000,000 in 2019 purchased as many as 78 subsidized housing units. In 2020 there was a very large increase, namely as many as 4,272 subsidized housing units were sold. 
The total purchase of subsidized houses in the year amounted to 77,835 units. Meanwhile, in 2020, the total purchase of subsidized houses has increased by 95,475 units. From the table it can be explained that there has been an increase in subsidized housing purchases from 2019 to 2020. Even with the COVID-19 pandemic, the intention of people with lower middle income to own a house remains and has increased. This increase also occurred because it was supported by government policies, one of which was the FLPP subsidized housing program as stipulated in the Regulation of the Minister of Public Works and Public Housing Number 20 / PRT / M / 2014. Realization of FLPP funds based on salary groups was mostly absorbed by groups with a salary of IDR $2,500,000<$ base salary < = IDR 3,500,000. this is not in accordance with the designation that the government provides subsidized housing to low-income people. In 2019 there was the realization of FLPP subsidized houses of 35,521 units and in 2020 there was an increase with the realization of FLPP subsidized houses of 40,904 units. However, a significant increase occurred in the salary group of IDR 3,500,000 < basic salary < = IDR $4,000,000$, namely in 2019 the realization of FLPP subsidized houses was 23,811 units and in 2020 there was a jump in realization of 8,886 units to 32,697 units. This can be seen in table 1 .

The government's allocation for FLPP is 102,500 units valued at Rp. 11 trillion, BP2BT 9,500 worth Rp. 380 billion and SSB 175,000 units worth Rp. 788 billion. SSB consists of 155,000 regular SSB KPR units and 20,000 SSB KPR units for ASN, TNI and Polri. Currently, the progress of FLPP activities has reached 77,050 units worth Rp. 7.8 trillion, BP2BT with 147 units worth Rp. 5.84 billion and SSB 4,067 units worth Rp. 1.53 billion. The subsidized housing program has been launched since 2015 to make it easy for low-income people to have decent and affordable housing, thereby improving the welfare of the community.

In table 2 it can be seen that FLPP funds were absorbed by various levels of society with various types of work. People with the type of civil servant work in 2019 bought 8,174 FLPP subsidized housing units, while in 2020 bought 9,596 FLPP subsidized houses. For people with the TNI / POLRI type of work in 2019, they purchased 3,583 FLPP subsidized housing units, while in 2020 it decreased by 20 units to 3,563 FLPP subsidized housing units. And for people with private types of work in 2019 bought 54,126 units of subsidized housing. In 2020, there was an increase so that the purchase of FLPP subsidized houses became 67,364 units. In 2019, people with self-employed occupations bought 8,945 FLPP subsidized housing units. And in 2020 there was a decline so that the purchase of subsidized houses became 7,187 units. Meanwhile, for other types of work, in 2019, 3,007 units of FLPP subsidized houses were purchased. And in 2020 it has increased by 7,764 units. Realization of FLPP funds based on the type of work occurred mostly in people with private occupations. In 2019, the realization of FLPP funds to buy subsidized houses was 54,126 units. And in 2020 there was an increase of 13,238 units, so that the realization of FLPP funds for the purchase of subsidized houses became 67,364 units.

The demand for housing in East Nusa Tenggara is still looking back at 90,535 houses. And there are 3,014,000 more housing units unfit for habitation. A house that is unfit for habitation is like a house made of walls, no electricity, no water, a bathroom / toilet. The general chairman of the DPD REI NTT targets to build 3,500 housing units by 2020 due to the high demand, especially in the city of Kupang.

Table 1. Realization of Subsidized Houses by Salary Group

\begin{tabular}{|c|c|c|c|}
\hline \multirow{2}{*}{ NO. } & \multirow{2}{*}{ Salary Group } & \multicolumn{2}{|c|}{ Year } \\
\hline & & 2019 & 2020 \\
\hline 1. & salary<=Rp1.000.000 & 404 & 251 \\
\hline 2. & $\begin{array}{l}\text { Rp1.000.000<salary<= } \\
\text { Rp1.500.000 }\end{array}$ & 1.332 & 1.255 \\
\hline 3. & $\begin{array}{l}\text { Rp1.500.000<salary<= } \\
\text { Rp2.500.000 }\end{array}$ & 16.689 & 16.096 \\
\hline 4. & $\begin{array}{l}\text { Rp2.500.000<salary }<= \\
\text { Rp3.500.000 }\end{array}$ & 35.521 & 40.904 \\
\hline 5. & $\begin{array}{l}\text { Rp3.500.000<salary }<= \\
\text { Rp4.000.000 }\end{array}$ & 23.811 & 32.697 \\
\hline 6. & salary > Rp4.000.000 & 78 & 4.272 \\
\hline \multicolumn{2}{|c|}{ TOTAL } & 77.835 & 95.475 \\
\hline
\end{tabular}

Source: Ministry of PUPR, compiled.

Table 2. Realization of Subsidized FLPP Fund by Type of Work Table

\begin{tabular}{|c|l|c|c|}
\hline \multirow{2}{*}{ NO. } & \multicolumn{2}{|c|}{ Type of Jobs } & \multicolumn{2}{c|}{ Year } \\
\cline { 3 - 4 } & \multicolumn{2}{|c|}{2019} & 2020 \\
\hline 1. & Government Employee & 8.174 & 9.596 \\
\hline 2. & Police/Army & 3.583 & 3.563 \\
\hline 3. & $\begin{array}{l}\text { Private } \\
\text { Employee }\end{array}$ & 54.126 & 67.364 \\
\hline 4. & Entrepreneur & 8.945 & 7.187 \\
\hline 5. & Others & 3.007 & 7.765 \\
\hline \multicolumn{2}{|c|}{ TOTAL } & 77.835 & 95.475 \\
\hline
\end{tabular}

The high population growth is not matched by an increase in income and welfare level for people with middle to lower income. Land is a non-renewable natural resource. So that the community, in this case the government, is required to utilize the land so that housing can be built which can be used as a habitable house for the community. 


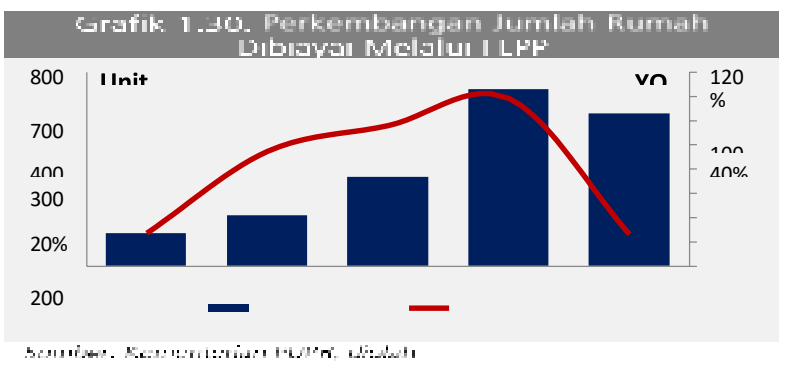

Figure 2. Development of Number of Houses Financed through FLPP

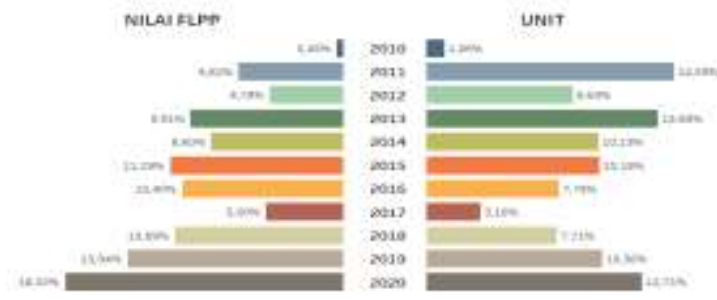

Figure 3. Realization of FLPP

Source: Ministry of PUPR, compiled

Table 3. Realization of FLPP

\begin{tabular}{|c|c|c|c|}
\hline No & Year & Value of FLPP & Unit \\
\hline 1 & 2010 & 242.627.216.215 & 7.958 \\
\hline 2 & 2011 & 3.688.302.870.380 & 109.593 \\
\hline 3 & 2012 & 2.587 .256 .538 .728 & 64.785 \\
\hline 4 & 2013 & 5.363.161.269.150 & 102.714 \\
\hline 5 & 2014 & 4.665.811.869.824 & 76.058 \\
\hline 6 & 2015 & 6.055 .259 .418 .208 & 76.489 \\
\hline 7 & 2016 & 5.627.426.494.807 & 58.469 \\
\hline 8 & 2017 & 2.706 .614 .592 .758 & 23.763 \\
\hline 9 & 2018 & 5.895.289.849.175 & 57.939 \\
\hline 10 & 2019 & 7.545.288.389.506 & 77.835 \\
\hline 11 & 2020 & 9.755 .336 .093 .071 & 95.475 \\
\hline \multicolumn{2}{|c|}{ Total } & 54.122 .374 .601 .821 & 751.078 \\
\hline
\end{tabular}

Source: Ministry of PUPR, compiled.

Meanwhile, getting a house that is decent and in accordance with the income is getting more difficult. For this reason, the government offers various assistance to meet the needs of these communities. The government through the Ministry of Public Housing and Public Housing (PUPR) answers the need for subsidized housing accompanied by high demand through FLPP assistance. FLPP funds that have been issued by the government to help people with low incomes so that they can have a dream house in 2020 and the realization is Rp. 9,755,336,093,071 (18.02\%) with 95,475 (12.71\%) units that have been used up. sold (graph 3).

From table 3 it can be seen that the development of the FLPP value fluctuates every year. This illustrates that the need for low-income people for subsidized housing is very high. The government sees the need for this house as a good economic prospect. From the real estate sector, the increase will affect various other business sectors. With the high demand for houses from the community, the government will prepare aid funds that will be channeled through banks so that they can be conveyed to people in need. Funds that have been disbursed will increase cooperation between the government and developers / contractors. The construction of these houses requires skilled personnel to design the house (architecture), construction workers (builders). And will turn on other business sectors. This effect is known as the domino effect. So that when the government distributes funds for subsidized housing, it will not only revive the real estate sector but also many other business sectors that will experience an increase.

Based on table 4, it is explained that the real estate business field in 2019 did not experience growth. One of the factors in this condition is the decline in house purchases for low-income people. The government has provided housing financing facilities for low-income people through the Housing Financing Liquidity Facility (FLPP). In 2019, the growth in the number of houses financed through FLPP decreased by $-13.82 \%$ (yoy). This decrease was influenced by the limitation of the FLPP quota nationally in 2019 and the end of the Housing Financing Liquidity Facility (FLPP) quota in 2019. If you look at the high demand for housing, especially subsidized housing, the government is expected to be more sensitive in responding to this in various ways. For example, by increasing the quota and FLPP funds. So that the purpose of holding this FLPP fund can be realized, namely the welfare of low-income people. And it is predicted to increase in the first quarter of 2020.

The real estate sector in the first quarter of 2020 grew by $0.26 \%$ (yoy), an increase compared to the fourth quarter of 2019 which contracted by $-0.74 \%$ (yoy). This condition was driven by the growth in home purchases for low-income people. The government has provided housing financing facilities for low-income people through the Housing Financing Liquidity Facility (FLPP). In the first quarter of 2020, the growth in the number of houses financed through FLPP in NTT province contracted by $-46.11 \%$ (yoy), improving compared to the fourth quarter of 2019 which contracted by $-56.04 \%$ (yoy). Real estate sector performance is predicted to slow in Q2 2020 as a result of Covid19, which has lowered people's income and purchasing power.

The real estate sector in the second quarter of 2020 experienced a decline of $-5.58 \%$ (yoy), this condition was due to the low income earned by low-income people due to Covid-19. This condition requires a temporary lockdown in NTT province. 
Table 4. Growth and Market Share of NTT Province GRDP by Business Field

\begin{tabular}{|c|c|c|c|c|c|c|c|c|c|c|c|c|c|c|}
\hline \multirow{2}{*}{ Kategxi } & \multirow{2}{*}{ Uraian. } & \multicolumn{4}{|c|}{2018} & \multirow{2}{*}{2018} & \multicolumn{4}{|c|}{2019} & \multirow{2}{*}{2019} & \multicolumn{2}{|c|}{2020} & \multirow{2}{*}{$\begin{array}{l}\text { Penga I } \\
2020\end{array}$} \\
\hline & & 1 & $\mathbf{1}$ & II & N & & 1 & $\|$ & II & N & & 1 & 11 & \\
\hline A & Frteriat, Ketutnes, dan Perkener & 230 & 408 & 150 & 4,31 & 3017 & 0,032 & 6,80 & 1,06 & 7,79 & 35 & 2,12 & $(0,35$ & 30,9 \\
\hline B & 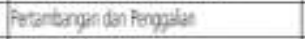 & $4 \pi$ & 33 & 28 & 2,55 & 1,94 & 6,22 & 5,59 & $2 \pi$ & $2 \pi 0$ & 332 & 0,18, & $(12,56)$ & 1,29 \\
\hline$c$ & ndasti fergoidan & 20,00 & 604 & 890 & 4,8 & $5 \%$ & $9 n$ & 2.53 & 10.54 & 1.20 & 4.14 & (3.28 & 14.100 & 1,30 \\
\hline D & Pongen litik tan $6 x$ & 2.54 & 429 & 505 & 112 & \$,5? & 3,5 & 2,45 & 15,10 & 2.35 & 082 & 1650 & $11 . \pi 5$ & 0,2 \\
\hline E & 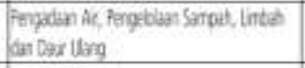 & 871 & 5.57 & $2 \pi$ & 5.17 & 5.47 & 5,29 & 6,43 & 675 & 321 & 54 & 2002 & 2,26 & $0, \%$ \\
\hline$f$ & consibji. & 6,64 & 531 & 6.63 & 699 & 639 & 5,76 & 2,34 & 0,75 & 818 & 4.45 & [201] & Q.82] & 9,52 \\
\hline G & 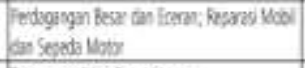 & 6,2 & 2,19 & 2,16 & 898 & 7, 球 & $8 \pi 7$ & 8.33 & 8,7 & 469 & 164 & 464 & 0,35 & 11,04 \\
\hline H & Furopraseiden Fagutingan & $8 \times 9$ & 203 & 20,17 & 7.19 & 2,92 & 5,45 & 7,25 & Uts & nos & 142 & 58 & 03,23 & 40 \\
\hline 1 & Fonejiar Honodes tan Nakan Moun & 1968 & 1733 & 5,50 & 4,13 & 12,5 & 9,16 & 8.21 & 567 & 137 & 598 & (565) & $(42,35)$ & 0,45 \\
\hline 1. & 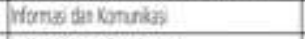 & 464 & 253 & 758 & 3,84 & 489 & 8,23 & 7,29 & 2,91 & 1,58 & 599 & 5,13 & 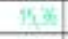 & 7,0 \\
\hline$x$ & Karkeangindar Agurs: & 4003 & 27 & 3,5 & 1.82) & 359 & 5,91 & $(1,8]$ & 5,4 & 379 & $12 \pi$ & 1,080 & 4,0 & 437 \\
\hline 1 & Fexitan: & $5 \pi 5$ & 7,06 & 527 & 0,54 & 435 & 4,5 & 0.25 & (3,45) & 10,7t) & 200 & 026 & 5.58 & 2.25 \\
\hline UII & Alat Pessitast & 483 & 217 & 23 & 요묘 & 1,87 & 49 & 394 & 5.24 & 18 & 38 & 0.87 & 02,518 & 0,4 \\
\hline 0 & 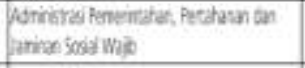 & 699 & 2,05 & 3.5. & 121 & $3,5 \%$ & 9.5 & 853 & 7,55 & $23 t$ & 817 & 526 & 6.5 & 14,4 \\
\hline$P$ & ina Pendokes & 0,56 & 6.5 & 485 & $3,5 ?$ & 241 & 823 & 608 & 7,6 & $Q, \bar{x}$ & 5,30 & 1290 & Q,38) & 9,33 \\
\hline 0 & sal Kextatin dan Kegeln Sosiel & 8.39 & 573 & 728 & 5,17 & 7,81 & 9,86 & 6,93 & 259 & $4 Q 2$ & 5,60 & 7,29 & 5,89 & 2,39 \\
\hline RST: & Finaticsit & 931 & 657 & 5,58 & 5,18 & 6,47 & 6.93 & 7,48 & 5.86 & 6.86 & 655 & 463 & 01,19 & 1,75 \\
\hline & PDRB & 5,01 & 5,00 & 5,14 & 5,34 & 5,13 & 532 & 635 & 381 & 5,32 & $\$, 20$ & 2,98 & $(1,96)$ & 10000 \\
\hline
\end{tabular}

Source: BI, compiled.

In table 5 it can be seen that in 2020 during the first quarter and second quarter the real estate sector (housing) experienced a decline. From 2,3.7 decreased to 2,25. During the first and second quarters, it was a time when Covid19 was rampant in almost all parts of the world including in the city of Kupang. During the Covid19 period, various health protocols were implemented that prioritize public health. One of them stayed at home. With these directions forcing every community to stay indoors. At that time, people will think of having their own comfortable house to live in.

In the midst of the Covid-19 pandemic, the real estate sub-sector has experienced a decline, only the subsidized housing segment has survived, consumers are still enthusiastic about getting subsidized housing. Typical people in Kupang city prefer to buy land and build houses according to their own wishes compared to buying subsidized houses. The community considers that the subsidized house model is limited, the land area obtained is limited. For several reasons, it can be seen in the table that the real estate sector in the first quarter and second quarter of 2020 experienced a decline. Compared to people in big cities, people in big cities will prefer subsidized houses because of limited land, the high price of land, while location is not a problem for people in big cities. For people in big cities, it is better to have a house that is far from all access compared to renting or living in strategic boarding houses.

Table 5.GDP Structure by Business Field in 2020

\begin{tabular}{|l|l|l|l|}
\hline \multicolumn{1}{|c|}{ Lapangan Usaha } & \multicolumn{2}{c|}{2020} \\
\cline { 3 - 4 } \multicolumn{1}{|c|}{$(1)$} & \multicolumn{1}{c|}{ Triwulan I } & \multicolumn{1}{c|}{ (2) (3) } \\
\hline \multirow{2}{*}{ A } & $\begin{array}{l}\text { Agriculture, Forestry, and } \\
\text { Fishery }\end{array}$ & 27,31 & 30,01 \\
\hline B & Mining and excavation & 1,14 & 1,09 \\
\hline C & Processing industry & 1,29 & 1,30 \\
\hline D & Procurement of Electricity and Gas & 0,08 & 0,08 \\
\hline E & Water Supply, Management Garbage, Waste and Recycling & 0,05 & 0,06 \\
\hline F & Construction & 10,19 & 9,52 \\
\hline G & Wholesale and Retail Trade; & 12,18 & 11,04 \\
\hline
\end{tabular}




\begin{tabular}{|c|c|c|c|}
\hline \multirow{2}{*}{\multicolumn{2}{|c|}{ Lapangan Usaha }} & \multicolumn{2}{|r|}{2020} \\
\hline & & Triwulan I & Triwulan ॥ \\
\hline & $(1)$ & (2) & (3) \\
\hline $\mathrm{H}$ & Transportation and Warehousing & 5,50 & 4,08 \\
\hline 1 & Provision of Accommodation and food and beverage & 0,68 & 0,46 \\
\hline j & Information and Communication & 7,01 & 7,70 \\
\hline K & Financial Services and Insurance & 4,28 & 4,31 \\
\hline L & Real Estate & 2,37 & 2,25 \\
\hline $\mathrm{M}, \mathrm{N}$ & Company Services & 0,29 & 0,14 \\
\hline $\mathrm{O}$ & $\begin{array}{l}\text { Government Administration, Defense and Mandatory } \\
\text { Social Security }\end{array}$ & 13,45 & 14,44 \\
\hline P & Education & 9,52 & 9,38 \\
\hline Q & Health Services and Social Activities & 2,39 & 2,39 \\
\hline$R, S, T, U$ & Other services & 2,24 & 1,75 \\
\hline
\end{tabular}

Source: BPS, compiled.

\section{CONCLUSION}

Based on the results of the research conducted, it can be concluded that:

1) The need for the real estate sector in the midst of the COVID-19 pandemic has decreased, but the need for subsidized housing is still in demand by consumers. The community with a salary group of Rp. 2,500,000 - Rp. 3,500,000 is the group with the most subsidized housing purchases in 2020. This explains that even with the ongoing Covid19 pandemic this has not dampened people's desire to buy subsidized housing to meet the need for shelter.

2) Realization of FLPP funds based on the type of work occurred mostly in people with private occupations. In 2019, the realization of FLPP funds to buy subsidized houses was 54,126 units. And in 2020 there was an increase of 13,238 units, so that the realization of FLPP funds for the purchase of subsidized houses became 67,364 units.

3) Consumption of FLPP subsidized houses during the first quarter and second quarter of 2020 has decreased. This is due to the decline in people's income and purchasing power due to the Covid19 pandemic that occurred.

4) In the realization of the FLPP subsidized housing implemented by the government, it was not well targeted. Because only a few people with a salary group of less than IDR 1,000,000 and a group with a salary of IDR 1,000,000 - IDR 1,500,000 can enjoy the FLPP subsidized house.

Decreasing incomes and people's purchasing power due to COVID-19 will hamper the growth of the real estate sector. And to overcome this, several ways are suggested, including:
1) Improve coordination between stakeholders (Ministry of PUPR, banks, and developers).

2) Expand the scope of various subsidy packages.

3) There are cheaper interest rates and longer tenors.

4) Reviewing all existing mechanisms related to subsidized housing financing (FLPP / SSB / SBUM. / BP2BT).

5) Accelerating the process and mechanism for financing stimulus provisions.

6) Better governance and transparency of public funds.

\section{REFERENCES}

[1] Republik Indonesia, Undang Undang Republik Indonesia Nomor 1 Tahun 2011 tentang Perumahan dan Kawasan Permukiman. 2011.

[2] P. R. Indonesia, "Undang-Undang Republik Indonesia Nomor 4 Tahun 1992 Tentang Perumahan Dan Permukiman," Undang. Republik Indones. Nomor 4 Tahun 1992 Tentang Perumah. Dan Permukim., 1992.

[3] R. Handoko and P. Patriadi, "Evaluasi Kebijakan Subsidi Non-BBM," Kaji. Ekon. dan Keuang., 2005.

[4] Bank Indonesia, "www.bi.go.id." [Online]. Available: www.bi.go.id.

[5] BPS, “www.ntt.bps.go.id." [Online]. Available: www.ntt.bps.go.id.

[6] Republik Indonesia, Peraturan Menteri Negara Perumahan Rakyat RI Perumahan Rakyat Nomor 05 Tahun 2005 tentang Pengadaan Perumahan dan 
Permukiman Dengan Dukungan Fasilitas Subsidi Perumahan Melalui KPR/KPRS Bersubsidi. 2005.

[7] Republik Indonesia, Peraturan Menteri Perumahan Rakyat RI Nomor 12 Tahun 2006 tentang Perubahan Atas Peraturan Menteri Negara Perumahan Rakyat Nomor 05 Tahun 2005 tentang Pengadaan Perumahan dan Permukiman Dengan Dukungan Fasilitas Subsidi Perumahan Melalui KPR/KPRS Bersubsi. 2006.

[9] A. Pnueli, In transition from global to modular temporal reasoning about programs, in: K.R. Apt (Ed.), Logics and Models of Concurrent Systems, Springer, Berlin, Heidelberg, 1984, pp. 123-144. DOI: https://doi.org/10.1007/978-3-642-82453-1_5

[10] B. Meyer, Applying "Design by Contract", Computer 25(10) (1992) 40-51. DOI: https://doi.org/10.1109/2.161279

[11] S. Bensalem, M. Bogza, A. Legay, T.H. Nguyen, J. Sifakis, R. Yan, Incremental component-based construction and verification using invariants, in: Proceedings of the Conference on Formal Methods in Computer Aided Design (FMCAD), IEEE Press, Piscataway, NJ, 2010, pp. 257-256.

[12] H. Barringer, C.S. Pasareanu, D. Giannakopolou, Proof rules for automated compositional verification through learning, in Proc. of the 2nd International Workshop on Specification and Verification of Component Based Systems, 2003.

[13] M.G. Bobaru, C.S. Pasareanu, D. Giannakopoulou, Automated assume-guarantee reasoning by abstraction refinement, in: A. Gupta, S. Malik (Eds.), Proceedings of the Computer Aided Verification, Springer, Berlin, Heidelberg, 2008, pp. 135-148. DOI: https://doi.org/10.1007/978-3-54070545-1_14 